\title{
A survey of microorganisms related to the biodeterioration of prehistoric paintings in natural shelters from Aragon (Spain)
}

\author{
J. M. Conzalez, and M.C. Portillo \\ INSTTUUTO DE RECURSOS NATLRALES Y AGROBIOLOGIA, CSIC, Avda. Reina Mercedes 10,41012 \\ Sevilla, Spain
}

The provnce of Aragon. on Northeastern Spain, presents an unusual richness of prehistoric paintings spread all over its territory. These paintings correspond to a wide chronological period ranging from the upper paleolithic to the recent prehistoric times. Current initiatives to preserve these shelters for future generations, are focusing on understanding the biogeochemical processes going on at these sites as a necessary step to better preserve these paintings. This study focuses on the microbiology of these shelters.

Molecular methods besed on the use of moleic acids were used to determine the micoorganisms inhabitunts of these sites. Molecular techniques are culture-ndependent methods. In this study, molecular techniques based on both DNA and RNA were utilized, so the cells present in these environments as well as the metabolically active microorganisms, respectively, can be differentiated during the experimental procedure

Durng this study, dwerse microbal communities were detected including a variety of members of different bacterial divisions. Alpha, Beta, Delta, and Gammaproteobacteria besides Acidobacteria, Actinobacteria, Bacteroidetes, and Planctomycetes were among the bacterial groups detected in these environments. The Gammaproteobacteria were the most abundant bacterial group in most of the collected samples. Communues tased on photosynthetic microorganisms such as Cyanobacteria and eukaryotic microalgae have been detected and showed vistle colonizations at some areas. The obtained results show a high complexity of the mitrobial communities present at these shelters. Understanding the functional properties of some of the components of these tricrobial conmunities together with the analysis of the envircmmental characteristics at these sites will contribute to the design of adequate conservation strategies.

Keywords bicdetericution, microbial communtes, prehistoric paintings 